\title{
SUBMARINE GROUNDWATER DISCHARGE REVEALED BY RADIUM ISOTOPES (Ra-223 and Ra-224) NEAR A PALEOCHANNEL ON THE SOUTHERN BRAZILIAN CONTINENTAL SHELF
}

\author{
Karina Kammer Attisano ${ }^{I,}{ }^{*}$, Isaac Rodrigues Santos ${ }^{2}$, Carlos Francisco Ferreira de Andrade, \\ Mariele Lopes de Paiva ${ }^{I}$, Idel Cristina Bigliardi Milani ${ }^{3}$ and Luis Felipe Hax Niencheski ${ }^{1}$ \\ ${ }^{1}$ Universidade Federal do Rio Grande (FURG), Instituto de Oceanografia \\ (Av. Itália, km 08, CP 474, 96201-900 Rio Grande, RS, Brasil) \\ ${ }^{2}$ Southern Cross University, Centre for Coastal Biogeochemistry, \\ School of Environmental Science and Management \\ (Lismore, NSW 2480, Australia) \\ ${ }^{3}$ Universidade Federal de Pelotas (UFPel), Engenharia Hídrica - CDTec \\ (Rua Gomes Carneiro, 01, Campus Porto, 96010-610 Pelotas, RS, Brasil) \\ *karina.attisano@gmail.com
}

\begin{abstract}
A B S T R A C T
Submarine Groundwater Discharge (SGD) has been recognized as an important component of the ocean-continent interface. The few previous studies in Brazil have focused on nearshore areas. This paper explores SGD on the Southern Brazilian Continental Shelf using multiple lines of evidence that include radium isotopes, dissolved nutrients, and water mass observations. The results indicated that SGD may be occurring on the Continental Shelf in the Albardão region, near a paleochannel located $50 \mathrm{~km}$ offshore. This paleochannel may thus be a preferential pathway for the delivery of nutrientand metal-enriched groundwater and porewater into continental shelf waters.
\end{abstract}

\section{RESUMO}

\begin{abstract}
A descarga de água subterrânea ("Submarine Groundwater Discharge"; SGD) é um importante elo entre continente-oceano. No Brasil, embora haja um crescente interesse em estudos sobre este tema, eles ainda são raros e se restringem às zonas costeiras. A presente investigação explora as evidências SGD na Plataforma Continental do Sul do Brasil, as quais incluem isótopos de rádio, nutrientes dissolvidos e distribuição das massas d'água. Os resultados indicam que a SGD pode ocorrer na Plataforma Continental na região do Albardão, próximo a um paleocanal localizado a $50 \mathrm{~km}$ da costa. Esse paleocanal pode, assim, ser o caminho preferencial de entrada de nutrientes e de águas subterrâneas ricas em metais na plataforma continental.
\end{abstract}

Descriptors: Porewater, Subterranean estuary, Permeable sediments.

Descritores: Água intersticial, Estuário subterrâneo, Sedimentos permeáveis.

\section{INTRODUCTION}

Submarine Groundwater Discharge (SGD) has been recognized as an important continentocean link (NIENCHESKI et al., 2007) which plays a fundamental role in the seaward transport of elements. It is significant for the geochemical cycle of marine environment and may drive primary productivity and eutrophication in coastal waters. Even though the transport of submarine groundwater is not as evident as the transport of river waters (BURNETT; DULAIOVA, 2003), the flow of groundwater may be responsible for greatly enriching superficial waters with nutrients and metals in coastal zones. Kroeger et al. (2007) reported that submarine groundwater has concentrations of nutrients orders of magnitude higher than those of surface waters. Windom et al. (2006) and Niencheski et al. (2007) have observed that groundwater-derived trace metal inputs into the ocean may be one order of magnitude higher than those of rivers into the ocean off Patos Lagoon. Cable et al. (1996) and Santos et al. (2010) have pointed out that the activities of radium isotopes may be from two to four orders of magnitude higher in submarine groundwater. Therefore, even small volumes of submarine groundwater discharge may carry significant amounts of elements to the ocean. SGD 
may, thus, be an important natural source of nutrients for primary productivity. In some cases, coastal eutrophication and primary productivity may be directly related to SGD (CORBETT et al., 1999; HUSSAIN et al., 1999). In addition, SGD may deliver gases from the bottom of the sea and create suitable habitats for benthic microorganisms and fauna (HOVLAND; JUDD, 1988; BUSSMANN; SUESS, 1998; STIEGLITZ, 2005).

Despite the fact that SGD is a common phenomenon in inshore regions close to beaches, the advection of submarine groundwater is not restricted to this zone; it may occur on larger spatial scales. Bratton (2010) demonstrates that confined aquifers may stretch along the coast quite extensively and reach the continental shelf several kilometers offshore. In some cases, deep aquifers may have fractures in confined upper layers - such as ruptures triggered by the depressions found along the shelf - which makes an exchange of fluids across the sediment-water interface possible. Santos et al. (2012b) have shown that various physical processes may control submarine groundwater discharge in areas on the continental shelf.

There are few studies of submarine groundwater discharge (SGD) in Brazil (SANTOS et al., 2008) despite the fact that there has recently been more interest in estimating SGD and in its potential influence on productivity in coastal zones. In fact, some important results have already been achieved in the southeastern (GODOY et al., 2006; OLIVEIRA et al., 2006; BURNETT et al., 2008; MOORE; OLIVEIRA, 2008; SMOAK et al., 2012) and southern regions of Brazil (WINDOM et al., 2006; NIENCHESKI et al., 2007; ATTISANO et al., 2008). However, direct SGD inputs into Brazilian offshore waters have not yet been addressed.

The objective of this investigation is to explore the evidence for submarine discharge on the Southern Brazilian Continental Shelf by collecting physico-chemical data, such as the distribution of the water masses and the behavior of nutrients and natural short-lived radium isotopes $\left({ }^{223} \mathrm{Ra}\right.$ and $\left.{ }^{224} \mathrm{Ra}\right)$. The main hypothesis is that groundwater is an important source of nutrients for the continental shelf off Rio Grande do Sul State, Brazil.

\section{Material And Methods}

Study Area

The Southern Brazilian Continental Shelf (SBCS) is about $140 \mathrm{~km}$ wide and is subject to several complex oceanographic processes that include the northward propagation of the Subtropical Front, the intrusion of important water masses and upwelling events. Sand substrate predominates in the internal shelf area. The exception is the area adjacent to the
Patos Lagoon mouth, where coastal mud deposits can be found (CALLIARI, 1997), and where there are biodetritic limestone deposits at depths of 25 to $40 \mathrm{~m}$ (CAPÍTOLI; BEMVENUTI, 2006). The SBCS comprises several depressions related to regression and transgression events of the sea level (ABREU; CALLIARI, 2005; CAMPOS et al., 2009).

In the Pleistocene regressive period, when the sea level reached its lowest point $120 \mathrm{~m}$ below its present level, the continental shelf was converted into a long coastal plain (ABREU; CALLIARI, 2005). The drainage of several fluvial systems reached the edge of the shelf and gave rise to several delta complexes. When the sea level started to rise again, it inundated the vast coastal plain, the deltas, the estuaries and other transitional environments.

There are several relatively deep and wide paleodrainage systems on the SBCS. The largest paleochannel (Fig. 1), known as the Albardão channel, is located on the southern limit of the inner and intermediate shelves. Beside the inner shelf in this channel, there are coastal sandbanks whereas on the intermediate shelf, there is a bank parallel to the channel, the Albardão Bank, which raises the seabed and thus decreases its depth from $75 \mathrm{~m}$ to $45 \mathrm{~m}$ (CAPÍTOLI; BEMVENUTI, 2006; CAMPOS et al., 2009). The SBCS is influenced by the Subantarctic Shelf Water (SASW) which determines both the low temperature at the bottom $\left(12-14^{\circ} \mathrm{C}\right)$ and the high phytoplancton productivity. The nutritional quality of the substrate is probably responsible for the large number of benthic organisms (CAPÍTOLI; BEMVENUTI, 2006) and promotes the development of pelagic and demersal fish on the shelf (CASTELLO; MÖLLER Jr., 1997).

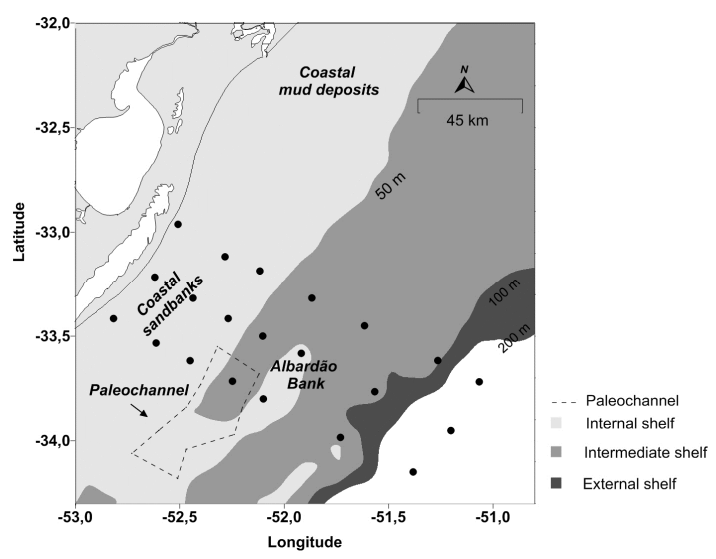

Fig. 1. The Southern Brazilian Continental Shelf, from the mouth of the Patos Lagoon to the south of the Mangueira Lagoon. The straight line represents the paleodrainage system (CAPÍTOLI \& BEMVENUTI, 2006); the dashed line represents the paleochannel in Albardão (CAMPOS et al., 2009). 
Field Samplings

Sampling was carried out on the Southern Brazilian Continental Shelf (offshore transect - across from the Albardão Lighthouse) from the Oceanographic Research Ship Atlântico Sul - FURG, in winter (August) 2005 and in the austral summer (February) 2007. A Rosetta, with Niskin bottles, coupled to a CTD device, was used for collecting samples at different depths as well as data on conductivity and temperature.

Nutrient samples were filtered through 0.45 $\mu \mathrm{m}$ cellulose acetate filters with a vacuum pump. The samples were then stored in polyethylene flasks and frozen. Reactants were added whenever necessary. The samples were then analyzed by the standard methods described by Baumgarten et al. (2010).

Measurements of ${ }^{223} \mathrm{Ra}$ and ${ }^{224} \mathrm{Ra}$ were carried out in subsurface waters using fibers impregnated with manganese oxide (MOORE, 1976). The radium samples were measured by the $\mathrm{RaDeCC}-$ Delayed Coincidence Counter - following Moore; Arnold's recommendations (1996).

Temperature and salinity values characteristic of each water mass were based on Möller Jr. et al. (2008). This approach allowed the identification of the classic T-S diagrams as described by Sverdrup et al. (1942) and Miranda; Castro Filho (1979).

\section{RESUlts AND Discussion}

\section{Water Masses}

In the austral summer (February, 2007), SASW was observed to weaken northwards (Fig. 2). Since SASW is a water mass with a broad salinity interval, ranging from 33.5 to 34.2 , due to the mixing of Subantarctic and Continental Waters, salinity cannot be used to determine whether or not there is a any fresh submarine groundwater seeping up from the paleochannel.

However, the intrusion of SASW through the Albardão Paleochannel may cause the advection of groundwater into the SBCS by the mechanism known as convection. Seasonal differences in temperature and salinity between the SASW $\left(\leq 14^{\circ} \mathrm{C}\right.$ in winter and $\leq$ $21^{\circ} \mathrm{C}$ in summer) (MÖLLER Jr. et al., 2008) and the interstitial waters of usually limited temperature variation may drive convection on the shelf. The intrusion of cold (and hence, denser) SASW into the paleochannel may lead to density inversion at the sediment-water interface and may potentially release the radium- and nutrient-enriched interstitial water. This process, which may occur in diverse environments, acts on temporal/spatial scales that may vary from hours to years and from centimeters to kilometers (SANTOS et al., 2012a). For instance, in Florida, groundwater reaches the shelf through fractures in the seabed and creates convection cells on a kilometer scale (KOHOUT, 1967). The balance of the interstitial and overlying waters involved in this mechanism may reach $0.14 \mathrm{~m} \mathrm{~d}^{-1}$ in estuaries (WEBSTER et al., 1996) and determine the chemical composition of estuarine waters (SANTOS et al., 2012a).

\section{Nutrients}

Silicate, a good groundwater tracer in coastal waters (KIM et al., 2005) (Fig. 3, $a$ and $b$ ), was enriched near the paleochannel areas when there was SASW intrusion up the paleochannel. This provides evidence for the advection of continental groundwater or porewater, known to be enriched in silicate and other nutrients (SANTOS et al., 2009) (Fig. 3).

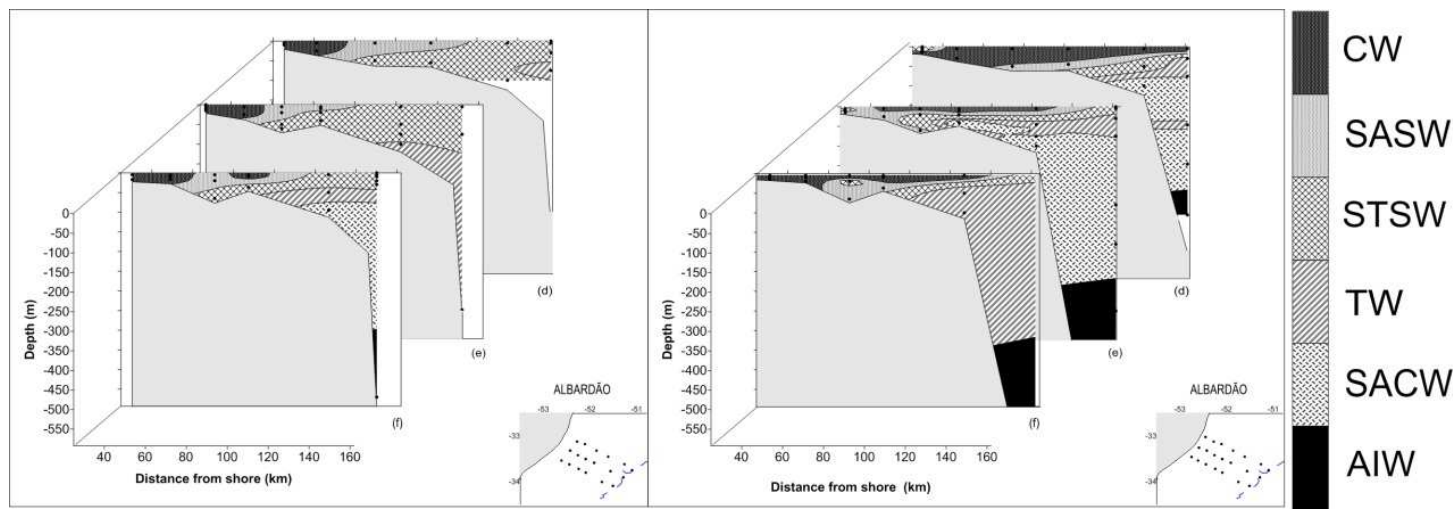

Fig. 2. Vertical distribution of water masses in the Albardão region in (A) winter and (B) summer: Coastal Water (CW); Subantartic Shelf Water (SASW); Subtropical Shelf Water (STSW); Tropical Water (TW); South Atlantic Central Water (SACW) and Antarctic Intermediate Water (AIW). 

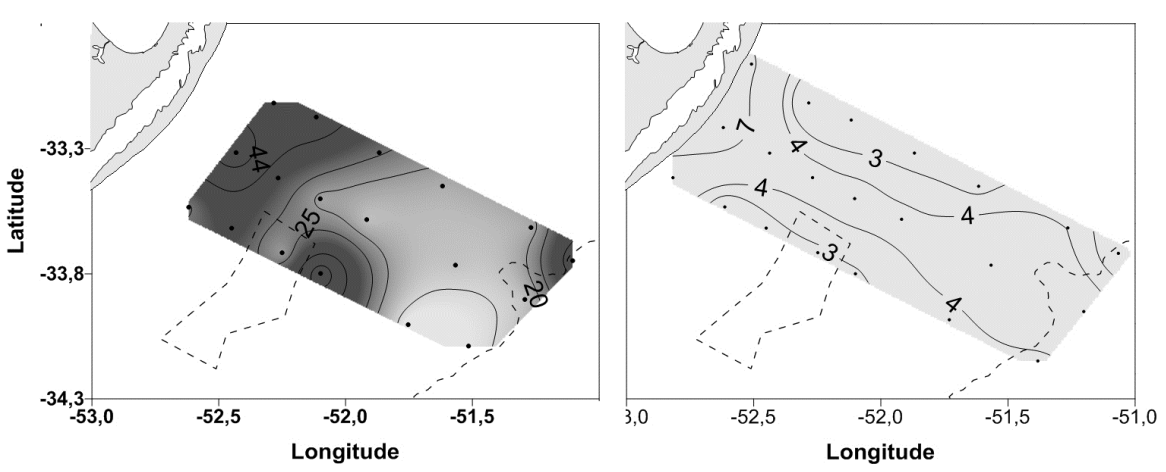

Fig. 2. Distribution of silicate ( $\mu \mathrm{mol} \mathrm{L-1)}$ ) along the transects offshore in (a) winter and (b) summer. The dashed line is the break on the shelf. The dashed line represents the paleochannel in Albardão (CAMPOS et al., 2009).

Core samples collected in the Albardão Paleochannel support this hypothesis. They shows that there is a higher water content (average: 50\%) along the profile than in other regions of the Southern Brazilian Continental Shelf. Besides, some clay deposits have even higher water-content. There is likely some recirculation of water in the sediments found in this depression, even though they may mostly consist of clay. Recent studies have shown that the activity of benthic microorganisms in impermeable clay sediments makes the transport of porewater through bioirrigation and burrows possible and that this significantly enhances the recirculation of seawater in sediments (MAHER et al., 2013).

\section{Radium Isotopes}

The distribution of short-lived radium isotopes $\left({ }^{224} \mathrm{Ra}\right.$ and ${ }^{223} \mathrm{Ra}$ ) showed a clear enrichment of isotopes nearshore and again at 50-100 km offshore (Fig. 4). The location of the offshore radium enrichment area indicates advection of groundwater on

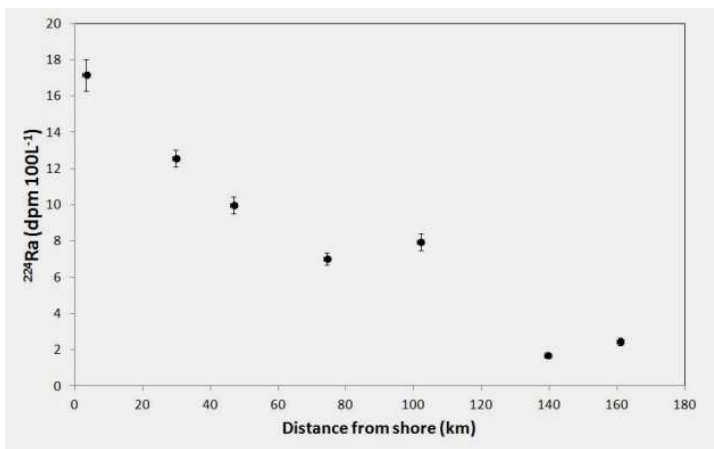

the Continental Shelf. The increase in the radium concentration between 50 and $100 \mathrm{~km}$ from the coast coincides with the location of the depression in the Albardão Paleochannel. Campos et al. (2009) indicated that the paleochannel starts exactly $50 \mathrm{~km}$ from the coast whereas its eastern margin stretches out as far as $90 \mathrm{~km}$ from the coast. The distribution of radium isotopes is thus consistent with our hypothesis that the paleochannel is a preferred pathway for groundwater or porewater exchange on the shelf.

Mulligan et al. (2007) also suggested that paleochannels in a coastal oceanic environment may be the preferential routes for the exchange between the seawater and aquifers. These authors have modeled the advection of groundwater in fluvial channels in North Carolina (USA) and have observed that even small paleochannels promote hydraulic connection between the aquifers and the sea, thus making the intrusion of seawater towards the continent and the discharge of fresh water offshore possible.

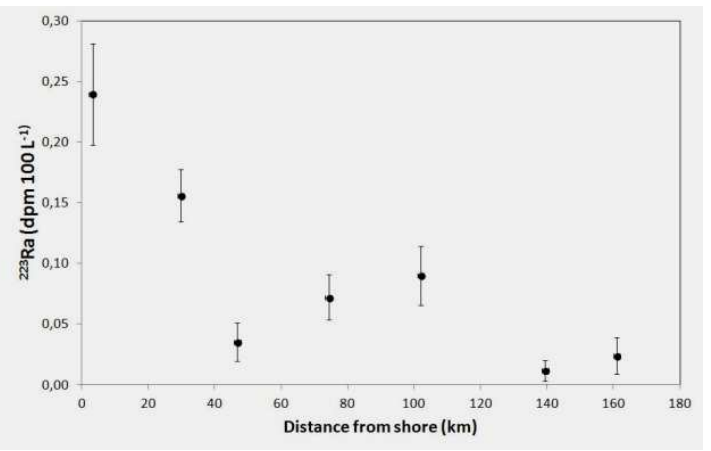

Fig. 4. Distribution of activities: (a) ${ }^{224} \mathrm{Ra}$ and (b) ${ }^{223} \mathrm{Ra}$, in transect offshore in austral winter. 


\section{CONCLUSION}

This study has described the following evidence suggesting enhanced groundwater advection on the continental shelf near the Albardão Paleochannel: (1) intrusion of SASW - through the paleochannel - which may lead to density inversions and favor advective exchange at the sediment-water interface; (2) high concentration of nutrients on the bottom which require an external source (likely groundwater) and cannot be explained solely by regional river inputs or seawater masses, and (3) increase in the activities of the radium isotopes in the paleochannel region. However, further studies, focusing on the use of four radium isotopes in vertical profiles in these systems, are called for to obtain quantitative information on the contribution of the paleochannel to regional groundwater exchange processes.

\section{ACKNOWLEGMENTS}

The authors wish to thank CAPES and $\mathrm{CNPq}$ for funding PRONEX 98 (Process no. 661102/98-0), for the Master's scholarship (CAPES) granted to the first author and for a Doctoral scholarship (Process no. 14210/2008-3), a Doctoral program abroad - SWE (Process no. 201576/2009-0) and a Post-Doctoral Program (Process no. 150775/2012-1). The authors also wish to thank CAPES/FAPERGS no. 9/2012 for a DOCFIX scholarship and Florida State University (Tallahassee, Florida, USA) for providing the structure for the analyses of natural radium isotopes.

\section{REFERENCES}

ABREU, J. G. N.; CALLIARI, L. J. Paleocanais na plataforma continental interna do Rio Grande do Sul: evidências de uma drenagem fluvial pretérita. Rev. Bras. Geofis., v. 23, n. 2 , p. 123-132, 2005.

ATTISANO, K. K.; NIENCHESKI, L. F. H.; MILANI, I. C. B MACHADO, C. S.; MILANI, M. R.; ZARZUR, S. Contribution from continental groundwater to the shelf zone in Albardão area, RS, Brazil. Braz. J. Oceanogr., v. 56, n. 3, p. 189-200, 2008.

BAUMGARTEN, M. G. Z.; WALLNER-KERSANACH, M.; NIENCHESKI, L. F. H. Manual de análises em oceanografia química. 2. ed. Rio Grande: FURG, 2010. $132 \mathrm{p}$.

BRATTON, J. F. The three scales of submarine groundwater flow and discharge across passive continental margins. J. Geol., v. 118, n. 5, p. 565-575, 2010.

BURNETT, W. C.; DULAIOVA, H. Estimating the dynamics of groundwater input into the coastal zone via continuous radon-222 measurements. J. Environ. Radioact., v. 69, n. $1 / 2$, p. 21-35, 2003

BURNETT, W. C.; PETERSON, R.; MOORE, W. S.; OLIVEIRA, J. Radon and radium isotopes as tracers of submarine groundwater discharge: results from the
Ubatuba, Brazil SGD assessment intercomparison. Estuarine, Coastal Shelf Sci., v. 76, n.3, p. 501-511, 2008.

BUSSMANN, I.; SUESS, E. Groundwater seepage in eckernfoerde bay (western baltic sea): effect on methane and salinity distribution of the water column. Cont. Shelf Res., v. 18, p. 1795-1806, 1998.

CABLE, J.; BURNETT, W.; CHANTON, J.; WEATHERLY, G. Estimating groundwater discharge into the northeastern Gulf of Mexico using ${ }^{222}$ Rn. Earth Planet. Sci. Lett., v. 144, p. 591-604, 1996.

CALLIARI, L. J. Geological setting. In: SEELIGER, U; ODEBRECHT, C.; CASTELLO, J. P. (Eds.). Subtropical convergence environments: the coast and sea in the Southwestern Atlantic. Berlin: Springer-Verlag, 1997. p. 13-18.

CAMPOS, P. C.; WEIGERT, S. C; MADUREIRA, L. Ecobatimetria e características acústicas do leito oceânico na região do canal do Albardão - Rio Grande do Sul Brasil. Rev. Atlântica, v. 31, n. 1, p. 5-23, 2009.

CAPÍTOLI, R. R.; BEMVENUTI, C. E. Associações de macroinvertebrados bentônicos de fundos inconsolidados da Plataforma Continental e Talude superior no extremo sul do Brasil. Rev. Atlântica, v. 28, n. 1, p. 47-59, 2006.

CASTELLO, J. P.; MÖLLER Jr., O. O. On the oceanographic conditions in the Rio Grande do Sul State. Rev. Atlântica, v. 2, n. 2, p. 25-110, 1997.

CORBETT, D. R.; CHANTON, J.; BURNETT, W.; DILLON, K.; RUTKOWSKI, C. A; FOURQUREAN, J. Patterns of groundwater discharge into Florida Bay. Limnol. Oceanogr., v. 44, p. 1045-1055, 1999.

GODOY, J. M.; CARVALHO, Z.; FERNANDES, F. C.; DANELON, O. M.; GODOY, M. L. D. P.; FERREIRA, A. C. M.; ROLDÃO, L. A. ${ }^{228} \mathrm{Ra}$ and ${ }^{226} \mathrm{Ra}$ in coastal seawater samples from the Ubatuba region - Brazilian southeastern coastal region. J. Braz. Chem. Soc., v. 17, n. 4, p. 730-736, 2006

HOVLAND, M.; JUDD, A. G. Seabed pockmarks and seepages: impacto $\mathrm{n}$ geology, biology, and the marine environment. London: Graham \& Trotman, 1988. 293 p.

HUSSAIN, N.; CHURCH, T. M.; KIM, G. Use of ${ }^{222}$ Rn and ${ }^{226} \mathrm{Ra}$ to trace groundwater discharge into the Chesapeake Bay. Mar. Chem., v. 65, p. 127-134, 1999.

KIM, G.; RYU, J. W.; YANG, H. S.; YUN, S. T. Submarine groundwater discharge (SGD) into the Yellow Sea revealed by $\mathrm{Ra}-228$ and $\mathrm{Ra}-226$ isotopes: implications for global silicate fluxes. Earth Planet. Sci. Lett., v. 237, n. 1/2, p. 156-166., 2005.

KOHOUT, F. A. Ground-water flow and the geothermal regime of the Floridian Plateau. Gulf Coast Association of Geological Societies Transactions, v. 17, p. 339-354, 1967.

KROEGER, K. D.; SWARZENSKI, P. W.; GREENWOOD, W. J.; REICH, C. Submarine groundwater discharge to Tampa Bay: nutrient fluxes and biogeochemistry of the coastal aquifer. Mar. Chem., v. 104, p. 85-97, 2007.

MAHER, D. T.; SANTOS, I. R.; GOLSBY-SMITH, J.; GLEESON, J.; EYRE, B. D. Groundwater-derived dissolved inorganic and organic carbon exports from a mangrove tidal creek: the missing mangrove carbon sink? Limnol. Oceanogr., v. 58, n. 2, p. 475-488, 2013.

MIRANDA, L. B.; CASTRO FILHO, B. M. Aplicação do diagrama T-S estatístico- volume à análise das massas de água da plataforma continental do Rio Grande do Sul. Bol. Inst. Oceanogr., v. 28, n. 1, p. 185-200, 1979. 
MÖLLER Jr., O. O.; PIOLA, A. R.; FREITAS, A. C. E CAMPOS, E. J. D. The effects of river discharge and seasonal winds on the shelf off southeastern South America. Cont. Shelf Res., v. 28, n. 13, p. 1607-1624, 2008. [Synoptic characterization of the Southeastern South American Continental shelf: the NICOP/Plata Experiment].

MOORE, W. S. Sampling 228Ra in the deep ocean. Deep-Sea Res. Oceanogr. Abstr., v. 23, n. 7, p. 647-651, 1976.

MOORE, W.S.; ARNOLD, R. Measurement of ${ }^{223} \mathrm{Ra}$ and ${ }^{224} \mathrm{Ra}$ in coastal waters using a delayed coincidence counter. J. Geophys. Res.: Oceans, v. 101, n. C1, p. 1321-1329, 1996.

MOORE, W. S.; OLIVEIRA, J. Determination of residence time and mixing processes of the Ubatuba, Brazil, inner shelf waters using natural radisotopes. Estuarine, Coastal Shelf Sci., v. 76, n. 3, p. 512-521, 2008.

MULLIGAN, A. E.; EVANS, R. L.; LIZARRALDE, D. The role of paleochannels in groundwater/seawater exchange. J. Hydrol., v. 335, p. 313-329, 2007.

NIENCHESKI, L. F. H.; WINDOM, H. L.; MOORE, W. S.; JAHNKE, R. A. Submarine groundwater discharge of nutrients to the ocean along a coastal lagoon barrier, southern Brazil. Mar. Chem., v. 106, n. 3/4, p. 546-561, 2007.

OLIVEIRA, J.; COSTA, P.; BRAGA, E. S. Seasonal variations of Rn-222 and SGD fluxes to Ubatuba embayments, Sao Paulo. J. Radioanal. Nucl. Chem., v. 269, n. 3, p. 689-695, 2006.

SANTOS, I. R.; COOK, P. L. M.; ROGERS, L.; DE WEYS, J.; EYRE, B. D. The "salt wedge pump": convection-driven porewater exchange as a source of dissolved organic and inorganic carbon and nitrogen to an estuary. Limnol. Oceanogr., v. 57, n. 5, p. 1415-1426, 2012a.

SANTOS, I. R.; PETERSON, R. N.; EYRE, B. D.; BURNETT, W. C. Significant lateral inputs of fresh groundwater into a stratified tropical estuary: evidence from radon and radium isotopes. Mar. Chem., v. 121, n. 1/4, p. 37-48, 2010.

SANTOS, I. R.; EYRE, B. D.; HUETTEL, M. The driving forces of porewater and groundwater flow in permeable coastal sediments: a review. Estuarine, Coastal Shelf Sci. v. 98 , p. $1-15,2012$ b.
SANTOS, I R; BURNETT, W. C; GODOY, J. M. Radionuclides as tracers of coastal processes in Brazil: review, synthesis, and perspectives. Braz. J. Oceanogr., v. 56, n. 2, p. 115-131, 2008.

SANTOS, I. R.; BURNETT, W. C.; DITTMAR, T.; SURYAPUTRA, I. G. N. A.; CHANTON, J. Tidal pumping drives nutrient and dissolved organic matter dynamics in a Gulf of Mexico subterranean estuary. Geochim. Cosmochim. Acta, v. 73, n. 5, p. 1325-1339, 2009.

SMOAK, J. M.; SANDERS, C. J.; PATCHINEELAM, S. R.; MOORE, W. S. Radium mass balance and submarine groundwater discharge in Sepetiba Bay, Rio de Janeiro State, Brazil. J. South Am. Earth Sci., v. 39, p. 44-51, 2012.

STIEGLITZ, T. Submarine groundwater discharge into the nearshore zone of the Great Barrier Reef, Australia. Mar. Pollut. Bull., v. 51, n. 1/4, p. 51-59, 2005.

SVERDRUP, H. U.; JOHNSON, M. W.; FLEMING, R. H. The oceans: their physics, chemistry, and general biology. New York: Prentice-Hall, 1942. 1087p.

WEBSTER, I. T.; NORQUAY, S. J.; ROSS, F. C.; WOODING, R. A. Solute exchange by convection within estuarine sediments. Estuarine, Coastal Shelf Sci., v. 42, p. 171183, 1996.

WINDOM, H. L.; MOORE, W. S.; NIENCHESKI, L. F. H.; JAHNKE, R. A. Submarine groundwater discharge: a large, previously unrecognized source of dissolved iron to the South Atlantic Ocean. Mar. Chem., v. 102 , n. 3/4, p. 252266, 2006.

(Manuscript received 13 September 2010; revised 27 April 2012; accepted 21 June 2012) 